\title{
メージャーエレメントの分析法としての発光分光分析
}

\author{
大 藤 能 親 ${ }^{*}$
}

(昭和 33 年 8 月 7 日受理)

\section{Emission Spectrochemical Analysis for the Determination of Major Elements Yoshichika OHTO}

(Industrial Research Institute Osaka Prefecture, Osaka)

In determining major elements by emission spectrochemical analysis, if the content of every other consituent element is small, no serious problem arises. But, if otherwise, the higher the content, the more the precision and accuracy of measurement are required.

As for the precision, it is of late almost unquestionably high since Quantometer has come into use and development and improvement have been made on equipments such as photoelectric direct reading device and a few others, enabling the appiication of emission spectrochemical analysis to be made widely in the field of high alloy and non-metallic compound studies.

But, when it comes to the analysis of complex high alloys, despite the use of multi-source emission that affords much better accuracy than with the conventional Feussner type emission method, numbers of standard samples for every alloy range are to be prepared in special cases to prevent the fall in accuracy by metallographical reason.

In the case of high alloys, improvement of accuracy by simplifying the measuring method and of technique of preparing samples to avoid segregation as much as possible is considered important as the remaining problem.

For non-metallic compounds, good precision and accuracy are now being obtained by fusing and homogenizing the material with lithium carbonate and borax, grounding and mixing it with graphite powder, then briquetting, in preparing the sample for analysis.

\section{1. 序論}

写真測定法による発光分光分析法は今日まで極微量元 素から数\%止りの定量分析には広く採用されて来た. メ ージャーエレメントを定量するに当つて各添加元素の含 有量がこの程度以下であれば写真測定法でも可能である が, 含有量が多くなれば精密度, 正確度の点よりして次 第に困難になるから当然分析の装置, 方法に改善がなさ れね汸なないのであるが，主要な点を要約すれ次次の 三項目になるであろう。

1）可検試料中の成分分布状態が極めて均質で放電箇 所がその試料の成分含有量を代表していること.

2）分光分析装置の定量精密度が高いこと.

3）可検試料を放電し各成分元素を気化，励起すると き共存元素, 試料履歴によつて影響されず正確度が高い こと.

近年カントメーターをはじめとして種々の光電直読式 分光分析装置が登場するに及び，その優秀な精密度，正 確度をもつて高含有量成分が実用的に定量可能となり, 発光分光分析の応用面が著しく広くなつた. 光電直読式 分光分析装置は今日では色んな型式のものが各社より発
売され夫々特長を有しているが，この詳細な機能上の間 題について注省略し，カントメーターを一例としてメ一 ジャーエレメント定量用としての進歩した個所をのべ, 今後の残された試料製作法の問題並に近年発達しつつあ る非金属物質への応用法について述べることとする。

\section{2. メージャエレメント定量用としてのカン トメーター}

カントメーターを良来の定量分光分析と各部に亘つて 比䡥するとき非常に沢山の進歩, 改良の跡が見られる. 例えば試料電極取付台に Petrey Stand を採用して電極 保持の機構が完全となり, 光学系上からも精密度学向上 せしめたとか色々の点をあげることが出来る．併し乍ら メージャーエレメント分析法としての最も顕著な進歩は 次の 4 項目をあげることが出来るので，以下これについ て述べよう.

a） Prism の代りに Grating の採用による Background の減少.

b）光電子増倍管を使用し直読式にしたがための測光

* 大阪府立工業奨励館 
精密度の向上 ${ }^{1) 23(3)}$ 4)

c) Sum Corrector による定量值補正法の採用5) 9) 12).

d) Multi Source 発光装置の採用による 正確度の向 上.6) 7) 8).

\section{2. a.}

カントメーターには Prism で分光しないで Concave な Grating 肪使用してある，この方法を使用して有利 な点は, 分散度が各波長域にわたつて等しい為に二次ス リットの背後の反射鏡, 光電子増倍管の配置が容易にな るという機構上の有利性があるが, メージャエレメント 定量といら観点よりすれば Background が Prism 分光 に比較して非常に少く, 従つて Line to Background Ratio が大であり, 定量值の精密度, 正確度を高める上 に極めて有利である.

\section{2. b.}

光電直読式の有利な点は今更述べるまでもないが，写 真測光法では乾板の銀粒子の大さとその分布性の外に現 像処理方法, 測光法等より相当の誤差が入る ${ }^{28)}$. これが 定量值に及ぼす影響は無視出来程度であるに反し, 光 電直読法では. Table 1 の如く $0.07 \sim 0.15 \%$ 程度であ るから実際上無視して差支えない程度である, 揭載した 表は各成分元素の検量線を求め定量可能な状態に維持し ている際にランプテストによつて求めた值であり, 各成 分元素の定量值より求めた標準偏差率に比較すれば極め て僅少である.

カントメーターを用いて実地に 4-6 真鍮中の $\mathrm{Zn}$ が Table 2 の如く化学分析值に対し比較的僅少のバラッキ をもつて定量出来ることは高合金についても正確度, 精 密度に関して既に実用化可能の段階になつた事を示して いるといえるであろう. 現在のカントメーターでは装置 の光学系の調整が完全であれば定量值の再現性の良否は 試料製作法, 発光法にかかつているといつて差支えない であろう・

\section{2. c.}

写真測定法による発光分光分析法では含有量の少い範 囲で定量するため標準試料中の主成分元素間の含有量に もとれ程差がなく, 彷つて定量值の補正という問題はあ まり取上げられなかつたが，可検成分元素の含有量が多 くなるに従い補正法の適用なくしては殆えど正確な定 量值を求めることが出来なくなつた. カントメーターの Recording System に Sum Corrector が設置してあつ て簡単迅速に補正值が求められる様にしてある. 併し標 準および可検試料の主成分元素の比率が 96〜 104\%の範 囲内に止つているので, より一層広範囲の補正の方法と
Table 1. Reproducibility of each channel.

\begin{tabular}{c|c|c|c}
\hline Recordidg Time & $\begin{array}{c}\text { Tube } \\
\text { No. 2 }\end{array}$ & $\begin{array}{c}\text { Tube } \\
\text { No. 1 }\end{array}$ & $\begin{array}{c}\text { Tube } \\
\text { No. 3 }\end{array}$ \\
\hline 34.8 & 69.2 & 66.8 & 57.2 \\
35.0 & 69.4 & 67.0 & 57.2 \\
35.0 & 69.3 & 67.0 & 57.2 \\
35.2 & 69.4 & 67.0 & 57.2 \\
35.0 & 69.3 & 67.0 & 57.2 \\
35.2 & 69.3 & 67.0 & 57.2 \\
35.2 & 69.2 & 66.8 & 57.3 \\
35.0 & 69.2 & 67.0 & 57.2 \\
35.0 & 69.4 & 66.8 & 57.2 \\
35.0 & 69.2 & 66.8 & 57.3 \\
\hline Mean Value & 69.29 & 66.92 & 57.22 \\
\hline Reproducibility (\%) & 0.13 & 0.15 & 0.07 \\
\hline
\end{tabular}

Table 2. Reproducibility of $\mathrm{Zn}$ in brass.

\begin{tabular}{|c|c|c|c|c|c|}
\hline \multicolumn{2}{|c|}{$\begin{array}{l}\text { Chemical } \\
\text { analysis }\end{array}$} & $37.14 \%$ & $30.89 \%$ & $38.54 \%$ & $21.48 \%$ \\
\hline \multirow{10}{*}{$\begin{array}{l}\text { Repeated } \\
\text { number }\end{array}$} & 1 & 37.30 & 30.75 & 38.55 & 21.52 \\
\hline & 2 & 37.00 & 30.89 & 38.70 & 21.48 \\
\hline & 3 & 36.90 & 30.83 & 38.51 & 21.30 \\
\hline & 4 & 37.14 & 31.07 & 38.65 & 21.45 \\
\hline & 5 & 37.33 & 30.75 & 38.47 & 21.55 \\
\hline & 6 & 36.94 & 30.98 & 38.55 & 21.48 \\
\hline & 7 & 37.60 & 31.07 & 38.47 & 21.55 \\
\hline & 8 & 36.85 & 31.20 & 38.47 & 21.52 \\
\hline & 9 & 37.16 & 30.88 & 38.40 & 21.45 \\
\hline & 10 & 36.98 & 30.93 & 38.76 & 21.45 \\
\hline \multicolumn{2}{|c|}{ Mean value $(\%)$} & 37.12 & 30.93 & 38.55 & 21.48 \\
\hline \multicolumn{2}{|c|}{$\begin{array}{c}\text { Reproducibility } \\
(\%)\end{array}$} & 0.63 & 0.46 & 0.27 & 0.34 \\
\hline
\end{tabular}

1) M. F. Haslar, H. W. Distert: J. Opt. Soc. Am., 38, 751 (1944).

2) M. F. Hasler, R. W. Lindhurt, J. W. Kemp: I. Opt. Soc. Am., 38, 789 (1944).

3) M. F. Hasler, R. W. Lindhurt, J. W. Kemp, M. C. Kraushaar: J. Opt. Soc. Am., 39, 1060 (1949).

4) 大藤, 笹倉, 浜口: 分光研究 第 10 号 (1954) 48 50.

5) M. F. Hasler: J. Opt. Soc. Am., 39, 1062 (1949).

6) M. F. Hasler: J. Opt. Soc. Am., 33, 688 (1943).

7) M. F. Hasler: J. Opt. Soc. Am., 34, 21 (1944).

8) 大藤, 浜口, 松本, 吉仲, 仲尾：日本金属学会誌, 第19 巻, 第12号 (1955) 696 700.

9) II: : " 第19巻, 第12号 (1955) 700 703.

10) II： I 第20巻, 第 6 号 (1956) 315 319.

11) II: I 第21巻, 第 1 号 (1957) 40 43.

12) " : " " " (1957) $43 \sim 46$. 
しては計算法，図式法をもつて行うことが出来る．銅合 金の場合には例光ば 50〜90\%の Cu の相違に対してで る適用する事が出来る．従つて金相学的影響が定量值に ないときは標準試料の種類も節減することが出来るけれ ども，日常の定量に於て単にこの様な補正の久では解決 出来奴現象が往経験される所である。銅合金について の研究により共存元素の影響がある場合には予め試料を 溶液化して影響を除去した後，本法による補正法を講ず ればはじめて正確な定量值が求められることが明らかと なつた。

\section{2. d.}

試料製作履歴が異るとか共存元素が存在するときには 定量値が化学分析値と著しくことなる現象がある.カン トメーターの使用により定量值の精密度が向上するに従 い，金相学的影響のある場合とそうでない場合とが逐次 各合金中の各元素について判つて来た9) 111 12) 15).

発光法の研究には精密度の向上と同時に正確度の向上 も目指しているが，正確度の方は特に電極材質の金相学 的問題と深い関連性があるので切離して考光られ好から カントメーターに採用されている Multi Source 発光法 を従来のFeussner Type の発光法と比較しつつ述べよ う.

試料電極の試料履歴がことなるか或は標集試料系に無 い他元素が可検試料中に含有される場合, 数多くの実験 研究の結果を綜合して考光られること就主成分元素, 可 検元素の輝線強度が異常に变化する場合があることであ る16). カントメーターの場合についていえば主成分元素 の輝線強度を光電流飞变光 Integrator に充電する時間 が標準のものと変ることを意味する．この様な場合には 試料電極の機械的性質特に硬度上の異常性が認められる ことが多い，経験を積み重䄈る事により金相学的な問題 は未然に大体予知出来るけれぞも，現在の所一般には標 準試料之可検試料とほ成分的にも金相学的にも可能な限 り近似せしめて影響を避けている。理想的な発光法によ つて火花間隙の気化立に励起条件制御し，輝線強度が 単に成分含有量によつてきまる様な発光法は未だない様 である。

発光法について注従来非常に多くの方式が研究さ机優 秀な発光法も発表さ机て来たが, カントメーターの High Precision Source Unit に附属する Multi Source はこ の中の一つと考光て差支光ないであるう.

従来より最もよく知られた Feussner 発光法は精密度 に関しては非常に申分のない発光法といえるであるう. カントメーターの High Precision Source Unit 中組ま

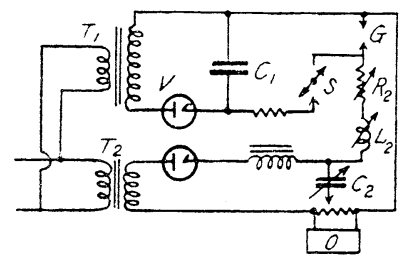
$\mathrm{T}_{1}$ : Trans. (Initiator)
$\mathrm{G}$ : Analytical gap
$\mathrm{T}_{2}$ : Trans.
$\mathrm{O}$ : Oscillograph
V: Rectifier
S : Rotary gap

Fig. 1. Multi source circuit.

れた High Voltage Spark Source は Feussner と大体 同様な蓄電火花発光法である.

この発光法法例えばアルミニウム地金等の定量分析に は良好な結果が得られるが，併し高合金の分析には正確 度の点より久て精密度程には良好な発光法ではない様に 思われる. Feussner Type の発光法は火花間隙電圧が 高いに拘わらず火花間隙の電流值は極めて低い，即ち標 準発光条件である $V_{2}=12000 \mathrm{~V}, C=0.003 \mu \mathrm{F}, L=0.08$ $\mathrm{mH}$ では実験の結果によれば電流経続時間が $27 \mu \mathrm{sec}$, , 最大電流值は $75 \mathrm{~mA}$ 程度である。これは必然的に試 料電極の気化作用が極めて 少いことを意味している.

Feussner Type の様な蓄電火花法に於ては顕微鏡写真 に利用される Cathodic Etching に類似の現象も若干含 まれているのが認められる場合もあるし，気化作用が少 いために試料履歷, 共存元素の影響をうけ気化条件も試 料ごとに変り易く, 又電極表面の組織状態によつては原 子濃度比も影響され易い. 火花間隙の条件が変れば発光 条件はたと元一定条件下で放電しても励起条件も变り, 放電の性質法火花的にも又弧光的にもなるから当然輝線 も性質に応じてその強度が変化する. カントメーターで 注写真測光法とはことなり線対の撰択制限をうけ，一 本の主成分元素の輝線に対する夫々各成分元素の輝線の 強度比で定量するから, この様な変化に対しては写真測 光法よりも不利である. 以上金相学的な影響を除去する ために注或程度気化作用が大でな⿰氵ればならない事が判 るが，さりとて直流弧光法の如き発光法では気化作用の 規則的な制御が不正確になり勝であるから精密度が良好 でない，一般て精密度と感度を両立させることは困難で あるが，Multi Source では Feussner Type の規則正

13）大藤：日本金属学会誌，第16巻, 第 8 号 (1952) 461 463.

14） II： II 第18巻, 第 8 号 (1954) 480 482.

15） II： " 第20巻, 第12号 (195. ) 683 687.

16) II： " 第20巻, 第12号 (195.) $687 \sim 691$. 
しい高速度断続装置を採用すると同時に Trigger Type の発光法を採用し比較的高電流を $C, L, R$ の撰択によ り流しうるから，気化作用も相当大きいので試料電極の 金相学的影響を或程度除きうる. 前にも記した如くカン トメーターの発光装置には Multi Source の外 High Voltage Spark Source も附属しているが, High Voltage Spark Source で高合金に対し所謂きれいな検量線 が描けない場合 Multi Source によつて解決した例が少 くない. 現今ではカントメーターの大部分の Reportが Multi Source によつたものであるということによつて もとの一端がうががる。

Multi Source を使用し写真測光法により鉄鋼中の $\mathrm{Cr}$ （1～30\%）の検量線を求めれば光電直読式でないため精 密度の低下はあつても検量線がきれいに描ける点よりし て正確度を高めるため写真測光法にても相当の利用価值 がある様に思われる。

\section{3. 試料製作法}

メージャーエレメントの定量には試料の製作法が特に 重要なことはいうまでもない.カントメーター用の試料 電極は Disk Type (非金属の分析に於ける Briquette 試 料もこの中に含まれる) の外 Pin Type のものや削り㕍 を圧縮したもの，溶液に対しては Rotated Electrode 法 も使用出来る. Disk Type のものと Pin Type の優劣 は仲々決定し難いが，発光分光分析法の特長の一つであ る迅速性という点と仮令試料放電面で若干の偏析はあつ ても同一面を繰返えし定量することにより成分偏析から 来る誤差を減少せしめるという点で，特殊な研究を除い ては Disk Type のものが一般に多く使用される現状で ある. Disk Type の試料についてみても製作法には鋳 造したままのものもあるし压延加工したものもある.今 日では標準試料電極は, 米国の National Bureau of Standard や英国の Bureau of Analized Samples Ltd. 等から発売されているが, Pin Type を主体にしている ものが多い，金属合金では標準試料製作にあたり偏析 ${ }^{17}$ という問題を切離して考えることが出来ないから信頼性 のある分光用標準試料の製作，特に Disk Type のもの の大量製造は至難な問題といわ视ばならない.乙かも成 分元素の配合範囲が実用合金の範域を甚しく外れている 場合とか，標準試料の製造上の履歴が可検試料のそれと 異るときは，正確度の面から定量值の信頼性がそしくな るから入手して直らに役立つ標準試料の数は案外少いの が普通である. カントメーターの製作者である A. R. L. 社でも標準試料は自工場で可検試料と同一条件下で注意
して製作する様推奨しているのもこの点から来ている様 である。

標準試料系の主成分含有量は略同樣に揃えることが出 来れ後の操作が非常に楽になるが，そうすれば可検成 分の元素の含有量比率に無理を来し，実用合金の範域を 脱するものが出来きれいな検量線が得られないととが多 い.これは高合金になる程甚しくなるから標準試料の配 合に注注意が必要である.なるべく標準試料系を沢山こ しらえる事によつてこの問題は解決出来る. カントメー ターの応用範囲を拡充する上に常につき当る障壁は良質 な標準試料の製造と入手といら事である. 自工場製のも のとか市販の金属材料中から精密度が良好なものを撰び 出して数力所で入念に JIS 標準化学分析法で分析し標集 分析值を求める.

これらの試料を用いて夫く或成分元素に関する検量線 を作製するが，最も信頼性のある標準試料をもつてこの 検量線で正確な定量值を与えるかどうか検討する.

カントメーターでは光電子増倍管の感度の時間的変化 がどうしても長時間の間には生ずるから，検量線の形状 も变るため時々 Restandardization を或成分元素含有量 の上限，下限のものを 2 個使用して行うが，標準試料中 の成分元素の偏析が甚しい程光電子増倍管の感度变動の 実態を知る事が困難になる。

成分的偏析を防止するため試料に詨し熱処理, 加工等 の操作を施して可及的に減少せしめる方法が最も妥当な 方法の一つと考えられる. 圧延した板材では組織は微細 化し偏析は圧延の程度に応じて減少するから鋳造試料上 り定量值の再現性が一般に良好である. 従つて熱処理, 加工した標準試料より求めた検量線を用いて鋳造した可 検試料を定量分析して正確度上に何等影響のない場合に は標準試料を熱処理加工して作製することが出来る. 併 し一般的には前にも述べた如く標準試料と可検試料とは 成分組成的にも製作履歴上からも出来る丈け等しい事が 望をしいから熔湯を汉取つて炉中の金属を品質管理する 様な場合標準試料も鋳造状態で作製する方が望ましい. 可検試料は大きな炉では大きい意味での成分組成の均一 性を見るため十分に多数の試料をとらなければならな w.

数年前 A.R.L. 社ではカントメータ一使用者側と提 携して種々の試料鋳造法の研究を行つていたが，それら の結果を綜合すると試料電極放電面の均等性は放電面を 急冷して鋳造する程良く，従つて定量值の精密度がすぐ れているとされていたが，1957 年 3 月米国 Pittsburgh で A.R.L. 社主催でアルミニウム生産業者間のカント 
メーター用試料電極作製法に関する懇談会が開催された 際 C. J. Clausen (Kaiser Aluminium \& Chemical Corp.) 洁 Book Mold, Center Powex Mold, Center Pour Copper Bottom Mold で比較した結果 abnormal variavility は型によつて変らないが, normal variavility は Copper Bottom のものがすぐれ，又 abnormal variavility 2 個鋳造したものの中最初のものに甚し いからこれは捨てるべきであると報告している．併しこ の様な方法で鋳造した場合放電面から内部にかけての成 分元素の分布状態は個々の試料について充分吟味, 検討 した上で標準試料として使用する必要があると思う.

可検試料の方は標準試料に準じて作製すればよいが， 可検試料作製上の履歴が不明であるとか著しい偏析のあ る可検試料では成分的に変らない様配慮して一度 Remelting 乙た後急冷して鋳造し使用することが出来る.

カントメーターの使用で精密度が向上したことは前述 したが，極端な表現法によれば装置の各部が完全に調整 され，且満足すべき状態下で運転されていれば，個なの 試料より得られる標準偏差率はとりも直さず各試料放電 面の各部に扮ける偏差の状態を示しているとさえ言える から標準偏差率は或特定試料に対する精密度である.

以上は金属合金の場合について述べたが，非金属質を 定量分光分析するときは適当な Flux を加えて完全に透 明なガラス状態に熔融し固化後, 粉砕しょく機械的に混 合して使用するから金属合金程には偏析はないものと思 われる．金属合金の場合試料電極の偏析を完全に解決す る方法としては溶液又は熔融状態13) 15) 18) に於ける定量 分光分析であるといら風に考えられる. 特に高周波熔融 法18) では迅速に熔融する事が出来, 且試料の攪汼が充 分であるから技術的な問題が解決出来れば理想的である う. 又溶液或は熔融試料では試料履歴, 共存元素の影響 が消去 ${ }^{15)}$ 出来るから熔融状態下に於ける分光分析は今後 に残された興味ある問題と思われる。

\section{4. カントメーター無機物質定量への応用 ${ }^{19-27)}$}

従来無機物質の分光分析法としては炭素電極に試料を 充填して発光せしめる方法が行われて来た. 本法は試料 材質の気化，励起がとかく不揃で当然精密度も良好とは いえない. 又多くの文献の示す如く Matrix Effect が あつて試料材質の物理的, 化学的性質の相違が正確度に 影響する. 例えば $\mathrm{Al}_{2} \mathrm{O}_{3}$ の状態が $\alpha$ か $\gamma$ かによつて 検量線も形状をことにする26).

併乙 A. R. L. 社の M. F. Hasller 等 ${ }^{19)}$ は次の方法 を発表し, カントメーターを用いて定量すれば精密度,
正確度共に高く, スラッグ, セメント, 硝子其他の高含 有量無機物の品質管理を可能とした.

即ら本法ではこれら無機物質は或程度粉砕して試料の 均質化をはかり例えば試料 1 に対し炭酸りチウム 0.5 , 無水研酸 0.5 安加入白金坩堝中で熔融する.熔融物は透 明となり完全均質化する.熔融物をステンレス鋼板上に 流し急冷固化後粗砕し瑪瑙乳鉢で機械的に粉砕後篩分け し（完全に試料の均質化がはかられているから節上，節 下では成分上の差はない） $10 \mu$ 以下のものを採り，乙れ に純 Graphite Powder (National Carbon 社の SP 1 の 如く Briquette 乙て固化するもの) 定等量加えてよく 混合した後 Briquetting Machine (A.R.L 製) を用い て $80000 \mathrm{lbs} / \mathrm{inch}^{2}$ の压力で普通 $\oint 1 / 2$ 时の試料を作製 する. こ机を適当な Holder にはめた後は常法の如く放 電, 発光して定量するのであるから, 単にカントメータ 一のみならず從来の写真測定法の分光分析にも応用する 事が出来る. 本方法では試料の均質化は充分であるが, 試料を熔融後粉砕したときの粒度, 試料に対する炭酸り チウム, 無水矹酸の混合比率, 混合の程度 Briquette 守 る際の圧力等の最適条件を撰べば可成り良好な精密度が 得られる。本法の応用範囲ほ極めて広いが. 一例として ポルトランドセメント中の各成分元素を定量した場合の 精密度を Table 3 にかがる。

\section{5. 結言}

メージャーエレメントの発光定量分光分析は可検成分 元素の含有量が少量の場合は写真測光法によつても可能 であるが, 含有量が多くなるに従い精密度, 正確度の点 よりして定量が困難となるが，カントメーターの出現に 伴い種々装置上, 方法上の進歩, 改良の結果, 金属合金 並に無機物質に対して実用上可能となつたとはいえ，分 析装置にかける以前の問題たる試料電極の均質性の良否

17) 万谷：大工奖館報 No. 8-1（1956） 25 29.

18) Leod, Frederickson, Jr. \& J. R. Churchill: Anal. Chem., 26, 5, 795 800 (1954).

19) M. F. Hasler \& F. Barley, Jr. : Applied Research Lab. Glendale, Calif. "The Direct-Reading Analysis of Steel-Making Slags "

20）松本，大藤：大工奨館報 18, 21 (1957).

21) 松本, 大藤： / 18,26 (1957).

22) 松本, 大藤: $\quad$ " 18, 29 (1957).

23) 松本, 松田: 分析化学, 投稿中

24）松本, 大藤：大工奨館報, 投稿中

26) 高瀬, 大藤, 松本, 竜門: “投稿中

27) 松本, 大藤： 11 投稿中

28）飯島：分光研究. 第 10 号, 33 (1954). 
Table. 3. Reproducibility of Various Components in the Portland Cement.

\begin{tabular}{c|c|c|c|c|c}
\hline No. & $\mathrm{SiO}_{2}(\%)$ & $\mathrm{Fe}_{2} \mathrm{O}_{3}(\%)$ & $\mathrm{MgO}(\%)$ & $\mathrm{Al}_{2} \mathrm{O}_{3}(\%)$ & $\mathrm{CaO}(\%)$ \\
\hline 1 & 21.60 & 2.27 & 1.45 & 4.58 & 63.20 \\
2 & 21.45 & 3.32 & 1.51 & 4.62 & 63.90 \\
3 & 22.10 & 3.25 & 1.51 & 4.62 & 63.90 \\
4 & 21.70 & 3.45 & 1.44 & 4.64 & 64.10 \\
5 & 21.65 & 3.27 & 1.48 & 4.64 & 63.59 \\
6 & 21.75 & 3.43 & 1.52 & 4.57 & 63.90 \\
7 & 22.70 & 3.43 & 1.47 & 4.61 & 63.50 \\
8 & 21.55 & 3.43 & 1.48 & 4.50 & 63.30 \\
9 & 20.75 & 3.30 & 1.41 & 4.67 & 63.30 \\
10 & 20.90 & 3.27 & 1.47 & 4.62 & 63.90 \\
\hline Mean value (\%) & 21.60 & 3.34 & 1.47 & 4.61 & 63.65 \\
\hline Chem. Anal (\%) & 21.55 & 36.3 & 1.50 & 4.48 & 63.87 \\
\hline Reproducibility (\%) & 2.20 & 2.46 & 2.35 & 1.04 & 0.51 \\
\hline
\end{tabular}

が金属合金中のメージャーエレメントの定量が更に正確 に行えるか否かの鍵を握つている様に考えられる．無機 物質への応用例が示す様に, 試料を完全に固溶体の状態 にもつて行くことが最良であるということは当然の事と 思われるが，金属合金の場合にはこの様な状態で試料を 作製することは望めないため, 試料を溶液或は熔融状態
にもつて行けば試料の均一性と同時に試料履歴, 共存元 素の影響の問題が解消するから技術的の面で解決すれば 一方法と思われる. 現在発光分光分析の応用が優秀な標 準試料の入手困難のために阻害されていると考えられる 面が少くないので, 組織的に見て無理のないすぐれた標 準試料系の作製方法の研究と製作が望ま机る次第であ る.
(21 頁より一ユネスコクーポン制度一続き)

$\begin{array}{llll}\text { Saar } & \times & \times & \times \\ \text { Sweden } & \times & \times & \times \\ \text { Switzerland } & \times & \times & \times \\ \text { Thailand } & \times & \times & \times \\ \text { Tunisia } & \times & \times & \times \\ \text { Turkey } & \times & - & - \\ \text { United Kingdom } & \times & \times & \times \\ \text { U.S. A. } & \times & \times & \times \\ \text { Viet-Nam } & \times & - & -\end{array}$

ユネスコ, クーポンは日本学術振興会（東京都台東区 上野公園日本学術会議内 Tel (82) 4,522. 4,523) で取 扱つている. 希望者は同会ユネスコ課に申請用紙がある から，申込めばよい，これに必要事項を記入し，同会に

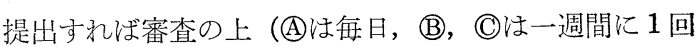
審査をする）これを公定相場による円貨でクーポンを販 売する. その際購入者は同会に対しクーポンの購入額の $4 \%$ の手数料安支払うことになつている. このクーポン に購入者の住所，氏名を記入して先方に送れ泣よい. 尚, 詳細柱同会発行の説明書を請求の上参照されたい。 